Farmer, T. A. (2009). Unique rural district politics. The Rural Educator, 30(2), 29-33.

\title{
Unique Rural District Politics
}

\author{
Tod Allen Farmer \\ Tarleton State University
}

\begin{abstract}
The politics of rural educational leadership are both intense and concentrated. Rural educational leaders need to be savvy and politically skilled if they are to inspire educational stakeholders and accomplish organizational objectives. The local school system is an organization with a political culture that can be characterized as a competitive environment in which various groups from both within and without are competing for power and limited resources. Local school systems are entrusted with both children and tax dollars, two precious resources. Coupled with such entrustment is political input from all points within the political continuum. Schools and politics are inseparable.
\end{abstract}

\section{Introduction}

"Today, education is perhaps the most important function of state and local governments (Brown v. Board of Education, 1954)." These reverberating words written so long ago in the landmark desegregation case still resonate today. Because of the importance of public education, it is subject to continual political scrutiny. The local school system is an organization with a political culture that can be characterized as a competitive environment in which various groups from both within and outside education are competing for power and limited resources. Local school systems are entrusted with both children and tax dollars, two precious resources. Coupled with such entrustment is political input from all points within the political continuum. Local education agencies and politics are inseparable. Piltch and Fredericks (2005) found, "As a principal, it is impossible to avoid situations where political considerations affect your decision-making” (p. 11). Rural educational leaders are not immune to such political pressures. Expecting such political considerations and proactively building collaborative partnerships are hallmarks of effective rural district leadership.

This article identifies many of the common political challenges faced by educational leaders in the rural district setting and provides recommendations for effectively accomplishing organizational objectives within a political environment. The major topics include the politics of finance, national mandates and their affect on rural schools, special interest groups, and trends toward privatization. The article concludes with a section dedicated to effectively navigating rural politics. The author seeks to assist rural educational leaders with the identification of potential political obstacles and equip such leaders with an enhanced ability to effectively lead within the politically charged context of the rural school district setting.

\section{Politics of Finance}

Rural districts face unique financial challenges that many urban districts do not face. For example, the large geographic size and lower population density of many rural districts increases transportation expenses. Urban districts often have the advantage of the economies of scale associated with dense populations. Additionally, while the small class sizes that some rural districts enjoy may lead to enhanced student achievement, it also leads to increased labor costs. Furthermore, rural districts have more limited abilities than urban districts to form financial partnerships with major corporations. Some rural districts face these challenges while simultaneously experiencing a declining enrollment. Collectively, these factors create funding challenges that are unique to the rural setting. Limited resources create varying degrees of funding ability for rural school systems. This in turn creates a culture in which competition for existing resources is necessary. Special interest groups from both within and without compete for existing resources. Funding priorities become the object of political debate at the local, state and national levels.

Who should pay for public education and at what level? Such questions evoke political responses. According to Stout, Tallerico, and Scribner (1994), "Excellence is given symbolic prominence, but not sustained financial support" (p. 15). Equity and adequacy in funding are continually debated both in the courtrooms and in local political arenas. McFadden (2006) found, "Too few state policy makers will support efforts to increase funding for education if it means either breaking their oath not to raise taxes or decreasing funding for other social services” (p. 13). Clabaugh and Clabaugh (2006) contended that the United States spends too much money on military action and too little on education. A California school superintendent Quon (2006) wrote, "Until we can get to adequate school funding, the 
demands of providing world-class standards to every California child remain elusive” (p. 11).

Both generating and expending tax payer dollars are politically charged actions. In addition to adopting the local tax rate for school maintenance and operation, the passing of school bond issues to finance school facilities can become very politically charged at the local school district level. This can be especially true when facilities such as new football stadiums are included in the bond issue. School board members, district employees, parents, students and community members often have diverging points of view.

Rural school districts face unique challenges when attempting to pass bond issues. Citizens might possess diverse opinions regarding the benefits of community growth. Community business groups might also be divided regarding capital outlay facility improvement projects. Businesses such as real estate companies, bankers and builders that stand to benefit from growth and increased property values frequently support such projects. Conversely, businesses that enjoy local monopolies frequently seek to maintain the status quo and thereby eliminate the increased competition associated with community growth. The latter can be especially challenging in a rural school setting.

Education in general is in many cases a major component of both national political party platforms and discussions at the local coffee shop. Rose (2004) found the following:

And, finally, education has become more politicized as we have moved from a society in which higher levels of education were considered the province of the few to one in which a highquality education is viewed as both a universal right and a necessity for individual welfare (p. 123).

Brimley and Garfield (2005) found that the constantly increasing financial burden on local school districts coupled with the simultaneous increase in state controls and standards has resulted in a challenge to the traditional notion of local control. The increase in standardization at both the state and national level has caused many local citizens to feel decreased influence.

\section{National Mandates and Their Affect on Rural Schools}

According to Brademas (1987), a democratic society must have an informed citizenry. Educated citizens rule themselves through elected officials. The proficiency of a democratic society's citizenry impacts the society's effectiveness in a global market. Thus, there is a federal interest in education because of the link to both national security and global competitiveness.

The Tenth Amendment to the United States Constitution delegated authority over education to the states. States vary from highly decentralized local education systems to more centralized state systems such as that of Hawaii. The recent trend has been movement toward increased state standards and accountability systems. Zeigler and Johnson (1972) found that business lobbyists have strong influences on state legislators, even on educational matters. Burbridge (2002) found, "These results confirm a role for interest groups in state education spending, particularly in terms of the level of effort states' [sic] undertake for education” (p. 253). According to McLendon and Ness (2003), in 2001, the Florida state legislature abolished the state university board of regents and established a new K-20 "superboard" to govern both K-12 and higher education. Since the new board members were handpicked by the state governor, the move was viewed as an effort to further politicize university governance. In 2002, a state constitutional amendment reversed the move and reestablished the statewide university board of regents.

Both national and state interests influence education in even the most rural school districts. In 1983, the National Commission on Excellence in Education released A Nation at Risk. The report called for a sense of urgency and refocused the nation's attention on education reform. $A$ Nation at Risk purported, "The citizen wants the country to act on the belief, expressed in our hearings and by the large majority in the Gallup Poll, that education should be at the top of the Nation's agenda.” In 2001, the Elementary and Secondary Education Act was renewed and renamed No Child Left Behind Act (2001). The No Child Left Behind Act (2001) was critical of public education. The executive summary of the act noted the "abysmal results" of public education. The focal point of the law was to increase accountability by identifying schools that were in need of improvement. The No Child Left Behind Act (2001) also called for "highly qualified" teachers in every classroom. According to Hickey (2006), The No Child Left Behind Act (2001) empowered knowledgeable parents with the ability to wage war against school administrators who were not responsive to parental educational decisions. As with the state interests, the recent trend at the national level has been movement toward increased standards and accountability systems.

\section{Special Interest Groups}

In addition to state and national interests, a variety of special interest groups exist at the local school system level. These can be especially intense in a rural setting. The athletic booster clubs, band booster clubs, parent and teacher associations, civic organizations and various other groups all wield political power. Additionally, supporters of academic programs such as the gifted and talented programs or the special education programs can be quite powerful. Smaller groups, such as cheerleader moms, can frequently be quite vocal in the local political process despite their relatively small size. Within the local school system, employees might be divided along faculty vs. staff lines or central 
office vs. campus level lines. This is especially true in states with strong teacher unions. Dow (1991) found that some interest groups seek to teach children how to think independently and how to explore the human condition while other interest groups seek to transmit prescribed facts and values. Each of these various groups can exert strong political influence at the local level. Balancing these interests can be a challenge for the local school administrator.

Some special interest groups can be very powerful locally. Football supporters can be a powerful force in many rural communities. In more highly populated areas, extremely large high schools can be the result of the political actions of football supporters who do not want to divide one highly competitive team into two less competitive teams. By influencing planning and zoning committees, water boards and various other local agencies, football supporters can attempt to exert influence on the local growth process in an effort to compete in a desired class bracket.

In addition to the usual school groups, ethnically diverse communities might become divided on school issues along ethnic or socio-economic lines. This can come into play when attendance zone boundaries are being redrawn. In an effort to maintain equity, attendance zone boundaries are often drawn to reflect district demographics rather than isolated affluent pockets within local school districts. Such zoning decisions often lead to political feedback.

Religion and political affiliation can also play a role in the politics of rural education. If members of a certain religious persuasion or political affiliation have dominant control of a local school board, they might seek to inculcate the local school system with their perception of community values. In rare, extreme cases, local school administrators can be faced with the law on one side and school board influence on the other. These situations are more common in a homogenous rural setting than they are in a diverse urban school setting. Such value laden religious positions are in no way unique to the United States. Jones (1979) described the late nineteenth century England conflict between church schools and board schools. Church and state issues and their related influence on education are debated in many countries across the globe. In some countries such as Afghanistan, religious influences have negatively impacted the educational opportunities of female and religious minority students. Despite the Jeffersonian separation of church and state that exists in the United States, religious interest groups can exert powerful political influence in the rural school setting.

One of the challenges of effective rural school leadership lies in balancing diverse special interest groups. Local school boards that hire superintendents and establish school policy are composed of representatives from various special interest groups. Alienating members of any of the various special interest groups can result in the election of new school board members. Subsequently, new local school leadership might follow in short order.

\section{Trends toward Privatization}

According to Bracey (2002), America's public schools as we know them are under attack. Such positions are themselves political in nature. Public education advocates and privatization groups often differ on local education policy positions. Whether because of educational, religious or economic motives, some interest groups would like to see the increased privatization of public schools. Private school voucher program alternatives offer choices for those who are disenfranchised with local public school systems. Public school advocates assert that privatization proponents can serve as negative political forces for local public school systems in an effort to further privatize public education. The issue remains highly political in nature.

School districts have regularly utilized private companies for services such as transportation, food service and custodial service. However, beginning in the 1990's, major districts across the country began to privatize their entire school operation. School districts in Baltimore, Detroit, Hartford, Miami and Minneapolis privatized their entire school systems (Gonzalez \& Wessely, 1995). These districts hired companies such as Education Alternatives, Inc., The Edison Project and Public Strategies Group to run the day-to-day operations of their districts. While complete district privatization efforts have been less common in rural districts, many rural districts privatize some of their district services. The degree of local school district privatization is a politically charged issue. In an era of scarce financial resources, some stakeholders in the local educational process can be attracted to the perceived potential cost savings purported with privatization efforts.

\section{Effectively Navigating Rural Politics}

Marshall and Gerstl-Pepin (2005) found, "Today the superintendent is often under attack and at the center of community conflicts” (p. 136). Conflict is an inevitable result of the local competition associated with the exercise of power and the allocation of limited resources. The exercise of power can shape the school curriculum. To a degree, the local school board can shape what is taught and how it is taught. Social issues decided by the Supreme Court such as prayer in school, evolution and abortion are politically charged issues. Spring (2005) found that religion plays a large role in local educational politics. Teachers, students and parents do not shed their views on these and other controversial issues when they enter the local school house doors. Even when local school administrators clearly communicate legal decisions and local policies, teachers sometimes exercise their personal views. According to English (1992), isolated teachers can exercise their own agenda once within the protection of their private classrooms. Value laden conflicts can occur over reading materials in the library, student dress codes, codes of conduct and a host of other issues. The varying political 
opinions that exist in a rural community will politically impact the local school system and inevitably result in conflict. Westheimer (2006) wrote, "To serve the public interest in democracy and to reinforce a democratic kind of patriotism, educators will need to embrace rather than deny controversy" (p. 620).

Politics are a reality in every local school system. Effective local school leaders must therefore learn to work within the unique political reality of their local system to accomplish organizational objectives. Bolman and Deal (2002) found that identifying key players is an important facet of political effectiveness. Furthermore, accurately assessing the political power of each of the identified key players is useful in making politically effective decisions. When common ground is lacking, focusing on mutually desired future outcomes can provide that common ground (Whitaker, 2001). Due to the reality of limited resources, it is impossible to be all things to all people. Limited resources will force difficult decisions. Empathic communication can be a powerful tool in minimizing the negative consequences of difficult decisions (Covey, 1989). The negative consequences associated with difficult decisions can be minimized by utilizing the following practices:

- Clearly communicate your organizational objectives

- $\quad$ Form coalitions with power players

- Befriend those who may resist change

- Clearly understand and empathize with varying points of view

- Be honest about divergent positions

- Include all stakeholders in the decision making process

- Collaborate

- Build partnerships for overcoming future challenges

Rural school leadership involves difficult choices. The effective leader must attain organizational objectives while simultaneously balancing diverse political interests.

Effective rural district leadership requires political competency on the part of the school leader. It requires good communication skills and proactive solutions to emerging conflicts. The development of interpersonal relationships facilitates the collaboration necessary to form coalitions and build partnerships. The savvy school leader recognizes the importance of political skills and diligently works to hone them. A gradual transformation occurs in which the school leader moves away from seeing political forces as obstructions to progress and toward visualizing political forces as integral stakeholders in the local educational process whose contributions are essential in the quest to achieve organizational objectives.

\section{References}

Arnold, M., Newman, J., Gaddy, B., \& Dean, C. (2005). A look at the condition of rural and educational research: Setting a direction for future research. Journal of Research in Rural Education, 20(6). Retrieved March 4, 2006 from http://www.umaine.edu/jrre/20-6.htm

Bolman, L. G., \& Deal, T. E. (2002). Reframing the path to school leadership: A guide for teachers and principals. Thousand Oaks, CA: Corwin Press, Inc.

Bracey, G. W. (2002). War against America's public schools: Privatizing schools, commercializing education. Boston: Allyn and Bacon.

Brademas, J. (1987). The politics of education: Conflict and consensus on Capitol Hill. Norman, OK: University of Oklahoma Press.

Brimley, V., Jr., \& Garfield, R. R. (2005). Financing education in a climate of change, $9^{\text {th }}$ ed. Boston: Allyn and Bacon.

Brown v. Board of Educ., 347 U.S. 483 (1954). Retrieved October 20, 2006, from

http://usinfo.state.gov/usa/infousa/facts/democrac/36.ht $\mathrm{m}$

Burbridge, L. C. (2002). The impact of political variables on state education policy: An exploration. Journal of Education Finance, 28(2), 235-260.

Clabaugh, G. K., \& Clabaugh, A. A. (2006, Summer). In this savage land: Schooling and American priorities. Education Horizons, 84(4), 208-213.

Covey, S. R. (1989). The seven habits of highly effective people: Restoring the character ethic. New York: Fireside.

Dow, P. B. (1991). Schoolhouse politics: Lessons from the Sputnik era. Cambridge, MA: Harvard University Press.

English, F. W. (1992). Deciding what to teach and test: Developing, aligning, and auditing the curriculum. Newbury Park, CA: Corwin Press, Inc.

Gonzales, G., \& Wessely, M. (1995). Private management of the schools: Solution for failing schools? Updating School Board Policies, 26(1), 1-4.

Hickey, M. E. (2006). Parents, power, and the politics of school reform. In F. M. Duffy (Ed.), Power, politics, and ethics in school districts: Dynamic leadership for systemic change (pp. 193-206). Lanham, MD: Rowman \& Littleton Publishers, Inc.

Jones, A. W. (1979). Lyulph Stanley: A study in educational politics. Ontario, Canada: Wilfrid Laurier University Press.

Marshall, C., \& Gerstl-Pepin, C. (2005). Re-framing educational politics: For social justice. Boston: Allyn and Bacon.

McFadden, B. W. (2006, January/February). The politics of adequate funding. Leadership, 35(3), 12-15.

McLendon, M. K., \& Ness, E. C. (2003). The politics of state higher education governance reform. Peabody Journal of Education, 78(4), 66-88. 
National Commission on Excellence in Education. (1983). A nation at risk: The imperative for educational reform (DHHS Publication No. ADM 065-000-00177-2).

Washington, DC: U.S. Government Printing Office. Retrieved October 19, 2006, from http://www.ed.gov/pubs/NatAtRisk/risk.html

No Child Left Behind Act, 20 USC § 6301 (2001). Retrieved October 29, 2006, from http://www.ed.gov/policy/elsec/leg/esea02/107-110.pdf

Piltch, B., \& Fredericks, R. (2005, January/February). Politics and the principalship: A principal's guide to school politics. Principal, 84(3), 10-14.

Quon, P. (2006, January/February). Adequate funding: A matter of political will. Leadership, 35(3), 11.

Rose, L. C. (2004, October). The politicization of K-12 education. Phi Delta Kappan, 86(2), 122-127.
Spring, J. H. (2005). Political agendas for education: From the religious right to the Green Party. Mahwah, NJ: Lawrence Erlbaum Associates, Inc.

Stout, R. T., Tallerico, M., \& Scribner, K. P. (1994). Values: The 'what' of the politics of education. In J. D. Scribner \& D. H. Layton (Eds.), The study of educational politics (pp. 5-20). New York: Falmer Press.

Westheimer, J. (2006, April). Politics and patriotism in education. Phi Delta Kappan, 87(8), 608-620.

Whitaker, T., \& Fiore, D. J. (2001). Dealing with difficult parents: (and with parents in difficult situations). Larchmont, NY: Eye on Education.

Zeigler, H., \& Johnson, K. F. (1972). The politics of education in the states. New York: Bobbs-Merrill Company, Inc. 